\title{
Good food for all
}

Food for the Future. By K. Campbell. Pp.178. (University of Nebraska Press: Lincoln and London, 1979.) £8.75.

FOR some years those whom the popular press call ecologists have been telling us that mankind is doomed to perish from starvation. They say that we are not producing enough to feed the present world population of four thousand million, and that the shortage of energy and other resources, and the damage intensive farming is doing to the environment, means that in the future we will produce less, not more food. As the population is expected to be over six thousand million by the year 2000 , and as it will probably increase further after that, the future seems desperate. Professor Keith Campbell believes that these doomsday men are "just plain wrong".

He is, of course, not the first to say this. Many agricultural scientists have suggested that, even without fundamental advances in farm practice, vastly greater productivity is possible in many parts of the world. The most striking report, published in 1975 by P. Buringh, H.D.J. van Heemst and G.J. Staring of the Agricultural University, Wageningen in the Netherlands, shows how the world's cereal production might be increased forty-fold. This would feed any possible population increase for many years to come.

Of course everyone, including Professor Campbell, must agree with the Malthusian view that if the world population continues to increase there must eventually be more than can be fed, but there are reasons for believing that this situation is a long way off, or, more hopefully, that population growth will be contained at a satisfatory level (as far as food production is concerned). This view is set out here, using familiar data, based on the fall in birth rate in both developed and developing countries. It is suggested that the most likely estimate is that the world population will stabilise at about eleven thousand million at the end of the twenty-first century; if so there is little doubt that they can all be fed.

Professor Campbell discusses the problems which will affect future agricultural productivity. He shows that these are of two types. First we have the scientific and agricultural problems - how much food can we produce; will there be land, water, energy and other resources; can the land sustain the present pressure? Secondly we have the economic and political problems - will farmers make a decent living; or will economic and social pressures make them work below their maximum level of productivity?

The first set of problems are dealt with briefly and in a familiar way. Even the most intensive systems use only a tiny fraction of the energy used by man in his other activities, so there should be enough for food production. Global supplies of fertilisers, including phosphate, are adequate for centuries. There is little evidence that food farming, no matter how intensive, is doing anything else than increasing the land's fertility.

Professor Campbell believes that productivity can be greatly increased if research is better organised to deal with the practical problems of the least productive countries. He is critical of much presentday research, particularly in universities, and complains that it is often divorced from the advisory ("extension") services. This view will be endorsed by many older agriculturalists in England and Wales, who regretted the post-War reorganisation which set up the National Agricultural Advisory Service (NAAS), taking advisory work from the universities, cutting off the research workers from the farmers, and producing the usual pullutation of unproductive bureaucrats. Nevertheless I fear that Campbell may be guilty of hubris, for assuming that more relevent research will certainly produce results which will improve food production. Unfortunately we cannot foretell the outcome of original research. But it will probably do some good, even if not as much as is here suggested.

The most interesting sections of this book are those which deal with the other constraints reducing potential food production. The environmentalists who wish to go back to peasant farming are given short shrift; Campbell believes that modern techniques, including chemicals, must be used efficiently, and that there need be no damage to the environment (even if some wildlife may be exterminated). More serious consideration is given to economic and political policies which encourage low productivity. Price control, quotas and other measures adopted by governments to influence agriculture receive severe and, to me, convincing criticism.

It is clear that poverty, not low food production, is the main cause of hunger in the world today. Wheat prices rose in 1973 because Russia had the money to buy a larger than usual share of the world surplus, thus pricing the poorer countries out of the market. This grain was bought to feed pigs, which had more economic power than starving peasants in the third world. Professor Campbell optimistically suggest that economic growth, world wide, will make increased food production profitable. Some readers will be more sceptical, but they will agree that it will be wise for greater food production, with greater self sufficiency, to be encouraged in poor countries, where internal food movements will be easier than between different sovereign states.

Incidentally, as a good economist, Professor Campbell wishes to give the customer what he wants. He has no time for the suggestion that the amount of animal protein in consumer diets should be reduced. Nevertheless it is realised that where intensively-kept livestock is fed on food which man could consume, more than half the protein and over $90 \%$ of the energy is wasted. Today world production is already sufficient to give more than the present population a nutritionally adequate, though dull, largely meatless diet. While we have surpluses, there is no reason why they should not be used to produce luxury food for the richer nations. Whether the rest of the world will ever be able to afford such diets is, in my opinion, doubtful. I am comforted by the knowledge that in a real crisis we could reorganise our feeding habits to ensure that the world's population could be adequately nourished. I only hope that Professor Campbell is justified when he says that "the world can look forward to substantially better diets in the future than were ever enjoyed in the past".

Kenneth Mellanby was on the staff of Rothamsted Experimental Station from 1955-61, and is author of Can Britain Feed Itself? 